\title{
Angst og depression: Emotionsregulering i psykoterapi
}

\section{Mia S. O'Toole \& Esben Hougaard}

Pyskologisk Institut, Aarhus Universitet mia@psy.au.dk

Aarhus Universitet

esbenh@psy.au.dk

O’Toole, Mia S. \& Hougaard, Esben.(2016) Angst og depression: Emotionsregulering i psykoterapi, Tidsskrift for Forskning i Sygdom og Samfund, nr. 24, 17-38

Emotioner er kommet $i$ fokus inden for en række videnskaber de sidste årtier, hvor man er begyndt at tale om affektive videnskaber, der bl.a. omfatter psykologi, neurovidenskab, medicin og sociologi. I denne artikel hævder vi, at emotioner er en funktionel størrelse, og at uhensigtsmæssig regulering af emotioner spiller en vigtig rolle ved psykisk lidelse. Vi fremhæver herefter nogle centrale emotionsreguleringsstrategier ved angstlidelser og depression og præsenterer på denne baggrund emotionsreguleringsterapi som et bud på en psykologisk behandling, der direkte retter sig mod emotionsregulering $i$ angst og depression.

Anxiety and depression: Emotion regulation in psychotherapy

There has been an increasing interest in emotions during the past couple of decades, reflected in a rapid growth of the affective sciences. In this article we argue that emotions serve important functions in human life and that adaptive emotion regulation is crucial for mental health. We review some of the central emotion regulation strategies in anxiety dis- 
orders and depression and describe how Emotion Regulation Therapy is aimed at targeting emotion dysfunction in so-called distress disorders.

\section{Introduktion}

Emotioner. Nogle emotioner fylder os med glæde, som når vi i øjeblikke smiler af lykke. Andre er så smertefulde, at vi brændende ønsker at slippe væk fra dem. Nogle emotioner er passende i en given social situation, andre kan være upassende og føre til afstandstagen fra omgivelserne. Sådan er der forskel på emotioner i deres oplevelsesmæssige udtryk, kropslige manifestation og de handletilbøjeligheder, de medfører. Fælles for emotioner er dog, at de er funktionelle. Emotioner signalerer nemlig, at der er noget personligt betydningsfuldt på spil i os selv eller i vore omgivelser, og de tilskynder os til relevant adfærd i forhold til disse signaler. Nedenfor vil emotioners rolle i angst- og depressionslidelser, samt i behandlingen af disse, blive beskrevet med fokus på James Gross' procesmodel for emotionsregulering. Emotionsreguleringsterapi vil blive præsenteret som et bud på en psykologisk behandling, der direkte targeterer emotionsregulering i angst og depression.

\section{Emotioner}

Begrebet emotion er blevet defineret på mange måder gennem historien, hvor forskellige teoretikere har tillagt forskellige komponenter af emotionen primær betydning, f.eks. kropslige symptomer eller bevidst kognition (Scherer, 2009). I dag synes der at være stigende konsensus angående en multikomponentiel forståelse af emotion (f.eks. Cole, Martin, \& Dennis, 2004; Keltner \& Gross, 1999; Sherer, 2000). James Gross (2014) repræsenterer en sådan forståelse og fremhæver tre definerende karakteristika ved emotioner. For det første opstår emotioner, når personen vurderer en indre eller ydre situation som relevant for personens velbefindende. Om en situation er relevant eller ej, afhænger af personens mål, og således spiller vurderings- eller "appraisal"--teorier (Lazarus, 1991; Roseman \& Smith, 2001) altså en vigtig rolle inden for nyere emotionsteori. Sådanne teorier antager, at emotioner opstår som følge af en vurdering af begivenheders betydning for personen. Nogle gange sker sådanne vurderinger hurtigt, implicit og automatisk; andre gange foregår de langsommere gennem bevidst og strategisk kognitiv pro- 
cessering (LeDoux, 1996; Ellsworth \& Scherer, 2009). For det andet er emotioner kendetegnet ved forandringer i flere domæner, herunder i det oplevelsesmæssige (også betegnet den bevidste følelse), fysiologiske og adfærdsmæssige domæne. Det tredje karakteristikum ved emotioner er, at de er funktionelle. Det vil sige, at de forbereder personen til at tage handling mod et personligt relevant mål ved at genere såkaldte handletilskyndelser. Personen med angst for at flyve vil eksempelvis ved tanken om at skulle flyve opfatte en fremtidig trussel. Emotionen angst vil her forberede personen oplevelsesmæssigt, fysiologisk og adfærdsmæssigt til handling mod at neutralisere truslen. Den subjektive oplevelse, gående på tanker og følelser, kunne f.eks. indeholde oplevelsen af angst og katastrofetanker som "jeg bliver lukket inde" og "der går noget galt". Fysiologiske forandringer kunne være kropslige responser, som f.eks. øget puls, svedtendens og rysten. Endelig kan adfærdsresponser lede til undgåelse, f.eks. helt at undlade at flyve.

Mennin og kolleger (Mennin \& Farach, 2007; Mennin \& Fresco, 2014) har særligt diskuteret emotionernes funktionelle rolle. Med udgangspunkt i Jeffrey Grays teori beskrives to overordnede motivationelle systemer, et adfærdsinhiberende sikkerhedssystem og et adfærdsaktiverende belønningssystem (Gray \& McNaughton, 2000; Higgins, 2001). Når systemerne aktiveres genereres emotioner, der således tjener enten hæmmende eller aktiverende funktioner ved, at personen stræber efter at opnå hhv. sikkerhed eller belønning. Sikkerhedssystemet aktiveres ved tilstedeværelsen af en potentiel trussel og hæmmer adfærd, der kan lede til negative resultater, f.eks. fysisk smerte. Det andet system, belønningssystemet, mobiliserer belønnings- og trivselsfordrende adfærd, når personen møder belønningsmuligheder i sine omgivelser. Disse to systemer betragtes som uafhængige, hvilket betyder, at de både kan aktiveres sammen og hver for sig. Denne uafhængighed understøttes bl.a. af forskelle i de to systemer, hvad angår neural aktivitet, neurokemi og adfærdstendenser (f.eks. Stein \& Paulus, 2009). Hvorvidt disse systemer aktiveres bliver afgjort af, hvilke stimuli personen såvel automatisk som strategisk vurderer som personligt relevante. For eksempel kan synet af en flyvemaskine føre til angst for den ene person, hvor det for en anden kan skabe positive forventninger. Personen med angst for at flyve opfatter sin sikkerhed som truet, medens personen, der ser frem til nye eventyr ved synet af flyvemaskinen, ser kommende belønning. Ofte vil vi som mennesker stå i en situation, hvor begge systemer er aktiveret, hvilket fører til en såkaldt motivationel konflikt (Mennin \& Fresco, 2014), udtrykt ved modsatrettede handletilskyndelser. En konflikt kan f.eks. opstå for personen med angst for at flyve, der samtidig brændende ønsker sig at rejse 
til udlandet. Denne person kan se belønningsulighederne ved at komme til et nyt spændende land, men tanken om at skulle flyve derhen er angstprovokerende.

\section{Emotionsregulering}

Når en emotionel reaktion er igangsat, kan individet gøre forskellige ting for at regulere reaktionen. Disse emotionsreguleringsprocesser har været genstand for megen opmærksomhed og forskning gennem de seneste snart 20 år. Emotionsregulering er med James Gross (Gross, 1998; Gross \& Levenson, 1997) som frontfigur blevet et selvstændigt forskningsfelt. Emotionsregulering defineres som individets såvel automatiske som strategiske regulering af emotionens udvikling (Gross, 1998; 2014). Gross har formuleret en meget indflydelsesrig procesmodel for emotionsregulering (se Figur 1).

$\begin{array}{lllll}\begin{array}{l}\text { Situations- } \\ \text { selektion }\end{array} & \begin{array}{l}\text { Situations- } \\ \text { modifikation }\end{array} & \begin{array}{l}\text { Opmærksom- } \\ \text { hedsallokering }\end{array} & \begin{array}{l}\text { Kognitiv } \\ \text { forandring }\end{array} & \begin{array}{l}\text { Respons- } \\ \text { modulation }\end{array}\end{array}$

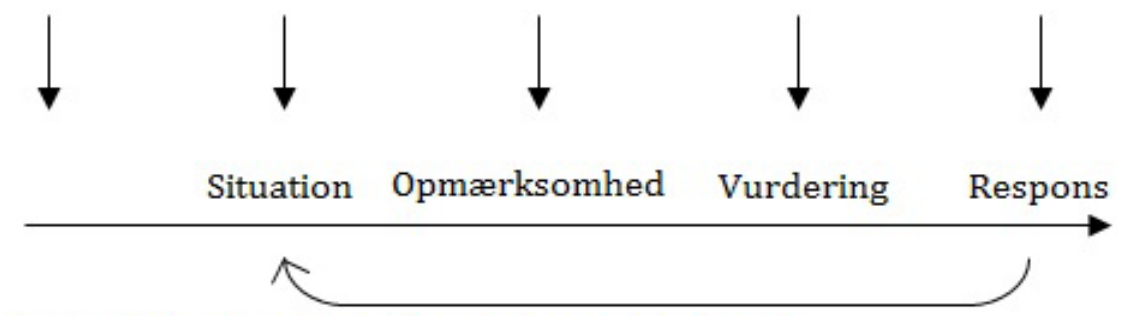

Figur 1: Procesmodel (Oversat efter Gross, 2014)

Modellen peger på, at en emotionel respons udvikles over tid: den opstår i en situation, hvor særlige stimuli tiltrækker opmærksomheden. Disse stimuli vurderes - automatisk eller bevidst - hvilket i sidste ende fører til en emotionel respons. Hvert af disse led i emotionsudviklingen kan gøres til genstand for særlige emotionsreguleringsstrategier, der falder i fem hovedkategorier. Fire af disse ligger forud for den emotionelle respons, medens den sidste, responsmodulation, finder sted efter emotionens opståen. De fire forudgående strategier omfatter situationsselektion, situationsmodifikation, opmærksomhedsallokering og kognitiv forandring. Når den emotionelle respons er udviklet, kan personen så forsøge at ændre eller modulere den vha. responsmodulerende strategier. I modellen er anført en pil fra denne emotionelle respons tilbage til situationen, som henviser til, at responserne 
ændrer på selve situationen. Reguleringsstrategier kan derudover have både et internt og eksternt sigte. Intern emotionsregulering henviser til personens forsøg på at regulere egne emotioner, hvor ekstern emotionsregulering går på at ændre andres emotioner.

Procesmodellen anfører typiske reguleringsstrategier på forskellige tidspunkter i emotionens udvikling, hvor de også vil have deres optimale effekt. De tidlige strategier kan dog anvendes efter, at den emotionelle respons er udfoldet. En strategi som kognitiv forandring kan således også anvendes til at dæmpe en emotionel respons, efter at den er opstået, selv om en sådan anvendelse ofte er mindre effektiv og mindre hensigtsmæssig (Goldin, McRae, Ramel, \& Gross, 2008; Gross, 2014). Nedenfor vil disse strategier blive beskrevet med nedslag fra forskningsresultater angående lidelsen socialfobi, der er defineret ved personens angst i sociale situationer (American Psychiatric Association, 2013), gående på angst for andres negative bedømmelse. Disse nedslag er alene tænkt som eksemplificerende i forhold til de forskellige reguleringsstrategier og deres konsekvenser og udgør således ikke en fyldestgørende beskrivelse af selve lidelsen socialfobi. For uddybende om socialfobi og emotionsregulering henvises til O'Toole (2014).

Situationsselektion går på individets til- og fravalg af situationer, baseret på en forudsigelse af hvilke situationer, der vil føre til hvilke emotioner. Personer med socialfobi vil ofte undgå en række situationer med det formål at dæmpe eller undgå angst (American Psychiatric Association, 2013). En sådan strategi kan have mange negative konsekvenser. Det kan f.eks. lede til problemer med at gennemføre en uddannelse pga. fravær (Ameringen, Mancini, \& Farvolden, 2003), og det kan lede til ensomhed (Lasgaard, Goossens, Bramsen, Trillingsgaard, \& Elklit, 2011).

Når en person først befinder sig i en emotionsfremkaldende situation, kan forskellige situationsmodifikationsstrategier benyttes. Sådanne strategier er rettet mod at ændre ydre træk ved en situation. Personer med socialfobi kan have vanskeligt ved selvhævdelse (f.eks. Grant, Beck, Farrow, \& Davila, 2007), hvilket kan anskues som manglende evne til at modificere situationen. Dertil benytter disse personer også en række sikkerhedsstrategier (Clark \& Wells, 1995; Wells et al., 1995). Det kan være, personen medbringer en ven til en fest eller tager en t-shirt på i en bestemt farve, der kan skjule sveden.

Strategien opmærksomhedsallokering har at gøre med måder, hvorpå individet kan styre sin opmærksomhed og lade forskellige genstande blive centrum for opmærksomheden. Personer med socialfobi kan have tendens til at være kritiske over for sig selv (Cox, Fleet, \& Stein, 2004) eller ruminere over fortidige hændelser 
(Abbott \& Rapee, 2004; Clark \& Wells, 1995). Sådanne strategier er kendetegnet ved, at personen har vanskeligt ved intentionelt at styre sin opmærksomhed væk fra det materiale, som selvkritikken og ruminationen omhandler (Mennin \& Fresco, 2013).

Den sidste forudgående strategi, kognitiv forandring, går på individets om- eller revurdering af situationen samt af egne evner til at håndtere situationen og beskrives generelt som en hensigtsmæssig strategi. Således rapporterer personer, der ofte bruger kognitiv revurdering, om højere livskvalitet (Gross \& John, 2003). Personen med socialfobi vil have dysfunktionelle tanker karakteriseret ved en tendens til at overvurdere både sandsynligheden af et negativt udfald (f.eks.: "det er helt sikkert, at jeg vil dumme mig") og konsekvensen ved selv samme (f.eks.: "jeg vil blive ydmyget for mine fejl") (McManus, Clark, \& Hackmann, 2000). At træne brugen af kognitiv revurdering i psykoterapi kan derfor være fordelagtigt. Vi fulgte eksempelvis 50 patienter med socialfobi gennem et kognitiv adfærdsterapeutisk forløb og fandt, at evnen til at tænke mere realistisk om sociale situationer og tænke mere accepterende om sin angst medierede effekten af kognitiv terapi på de socialfobiske symptomer (O'Toole, Mennin, Hougaard, Rosenberg, 2014).

Endelig er der responsmoduleringsstrategierne, som personer kan benytte til at ændre den emotionelle respons. Emotionsundertrykkende strategier er ofte blevet betegnet uhensigtsmæssige. De er defineret ved personens forsøg på at undertrykke såvel indre emotionelle fornemmelser som ydre emotionelle udtryk (Dunn, Billotti, Murphy, \& Dalgleish, 2009; Werner \& Gross, 2010). Det er blevet vist adskillige gange, at emotionsundertrykkelse typisk $i k k e$ leder til mindre negativ emotionel intensitet (Gross, 1998, 2014, Gross \& John, 2003) og faktisk giver øget aktivitet i det sympatiske nervesystem, som til dels er ansvarlig for generering af stressresponser (f.eks. Gross, 1998; Richards \& Gross, 2000). Emotionsundertrykkelse er også blevet associeret med en række negative konsekvenser, herunder ringe livskvalitet, mindre social støtte (f.eks. Gross \& John, 2003; Srivastava, Tamir, McGonigal, John, \& Gross, 2009) og kognitive vanskeligheder (Dunn et al., 2009; Richards \& Gross, 2000, 2006). Personer med socialfobi benytter en række undertrykkende strategier, både gående på at undertrykke indre fornemmelser (f.eks. hjertebanken) samt emotionelle udtryk (f.eks. rødmen) (Dalrymple \& Herbert, 2007; Kashdan \& Steger, 2006; Turk, Heimberg, Luterek, Mennin, \& Fresco, 2005), hvilket kan lede til nedsat verbal indlæring ( $\mathrm{O}^{\prime}$ Toole, Pedersen, Hougaard, \& Rosenberg, 2015) og forringet livskvalitet (O'Toole, Jensen et al,. 2014). 


\section{Psykisk lidelse og (u)hensigtsmæssig emotionsreguleringi}

Emotionel dysregulering er selvsagt ikke specifik for socialfobi. Psykiske lidelser omtales på engelsk som emotionelle forstyrrelser, og langt de fleste psykiske lidelser er kendetegnet ved brug af strategier, der måske eller måske ikke på den korte bane nedbringer negative emotioner, men på den lange bane er vedligeholdende for lidelsen (Gross \& Muños, 1995; American Psychiatric Association, 2013). Men hvad skal disse mennesker sætte i stedet for - med andre ord - hvad er såkaldt adaptiv eller hensigtsmæssig emotionsregulering?

Hensigtsmæssig emotionsregulering er blevet defineret på forskellig vis indenfor forskellige terapeutiske traditioner. Siden modellen af Gross blev formuleret og har vundet indpas, er man blevet opmærksom på, at emotionsregulering må ses i forhold til kontekstuelle faktorer. Senest er adaptiv, eller hensigtsmæssig, emotionsregulering således blevet defineret ved, at personen fleksibelt anvender forskellige emotionsreguleringsstrategier på en måde, så personen opnår sine mål (Aldao, Sheppes, \& Gross, 2015; Gross, 2014; Werner \& Gross, 2010). Først og fremmest skal personen have et emotionsreguleringsrepertoire, dvs. han eller hun skal kunne benytte forskellige strategier. Disse skal så anvendes på fleksibel vis, således at personen afstemmer brugen af forskellige strategier i forhold til konteksten bredt forstået, herunder trinnet i emotionsudviklingen, emotionens art og styrke, karakteristika ved situationen og de mål, som personen har i situationen. At undertrykke sit emotionelle udtryk kan således i nogle situationer være ganske adaptivt. Det kan f.eks. være i overensstemmelse med et personligt mål at undertrykke angst til en jobsamtale, hvor man vil højne chancerne for at få jobbet ved at fremstå fattet og rolig. Er målet derimod at opnå følelsesmæssig fortrolighed i et parforhold, er det selvsagt uhensigtsmæssigt helt at undertrykke sine emotioner. Derfor kan de individuelle emotionsreguleringsstrategier ikke kategoriseres som enten adaptive eller maladaptive, det kan kun deres anvendelse. Der er aktuelt behov for mere teoriudvikling og empirisk afprøvning mht., hvad man kan betragte som adaptiv emotionsregulering. Man ved dog, at en række faktorer kan være afgørende for individets evne til adaptivt at regulere sine emotioner, hvoraf her skal nævnes to: Emotionel reaktivitet og emotionsforståelse. 


\section{Emotionel reaktivitet}

Forøget emotionel reaktivitet, det vil sige en tendens til emotionelt at reagere kraftigere på emotionelle stimuli, er en afgørende faktor for personens mulighed for adaptivt at kunne anvende emotionsreguleringsstrategier. Det har vist sig, at normale personer vælger forskellige emotionsreguleringsstrategier afhængig af den emotionelle intensitet. Ved lav intensitet vælges kognitiv revurdering, hvor distraktion vælges ved høj intensitet (Sheppes, Scheibe, Suri, \& Gross, 2011). At normale personer udviser et sådant mønster i forhold til valg af reguleringsstrategi kan tolkes som et udtryk for adaptiv emotionsregulering, idet de tilpasser strategien til konteksten - i dette tilfælde emotionel intensitet. Angst- og depressionslidelserne er derimod karakteriseret ved øget emotionel reaktivitet (Mennin \& Fresco, 2013, 2014), og mennesker med disse lidelser vil således både oftere og med mere intensitet opleve negative emotioner. Som det er påpeget ovenfor, har de forskellige strategier deres optimale effekt på forskellige tidspunkter i udfoldelsen af den emotionelle respons. Hvis personen udviser en øget emotionel reaktivitet, vil tidsrummet for effektivt at kunne benytte forudgående strategier mindskes. Personen kan da risikere at anvende en række forudgående strategier uden at opnå den ønskede effekt. Det er i den forbindelse gentagne gange blevet påvist, at en angst- eller stressrespons nedsætter individets evne til at mobilisere tænkning og opmærksomhed, hvilke er nødvendige for eksempelvis at lave en kognitiv revurdering eller effektivt at rette sin opmærksom mod noget bestemt (Goldin et al., 2008; Ochsner, Bunge, Gross, \& Gabrieli, 2002).

\section{Emotionsforståelse}

En anden faktor, der menes at have afgørende betydning for individets evne til adaptiv emotionsregulering, er emotionsforståelse. Emotionsforståelse dækker over individets evne til at 1 ) identificere egne og andres oplevede og udtrykte emotioner, 2) forstå hvilke emotioner, der er passende i forskellige kontekster og 3) forstå årsager og konsekvenser af emotioner (definition tilpasset og oversat fra Eisenberg, Hofer \& Vaughan, 2007, s. 296). Særligt ét aspekt af emotionsforståelse har været genstand for empirisk undersøgelse, nemlig emotionsdifferentiering, som henviser til personens mere eller mindre nuancerede opfattelse af sine emotioner (Barett, Gross, Christensen, Benvenuto, 2001). Personer er altså forskellige i deres evne til at opfatte nuancerne i deres emotionelle oplevelse, hvilket har vist 
sig at være associeret med emotionsregulering. For eksempel har et studium vist, at individer med en nuanceret forståelse af egne negative emotioner var mere tilbøjelig til i det hele taget at benytte sig af emotionsregulering (Barett et al., 2001). Et andet studium har vist, at emotionsdifferentiering hos en gruppe af universitetsstuderende forudsagde de studerendes indtag af alkohol, der også kan opfattes som en (oftest uhensigtsmæssig) emotionsreguleringsstrategi. Studerende med den højeste emotionsdifferentiering indtog således mindst alkohol (Kashdan, Ferssizidis, Collins, \& Muraven, 2010).

Emotionsforståelse er også fundet nedsat ved angst og depression (f.eks. Marchesi, Brusamonti, \& Maggini, 2000; Mennin, Heimberg, Turk, \& Fresco, 2005; O'Toole, Hougaard, \& Mennin, 2013). På nuværende tidspunkt er det uklart, præcis hvilken betydning emotionsforståelse har for valg af emotionsreguleringsstrategi blandt disse lidelser. Et studium har dog f.eks. fundet, at personer med et højt niveau af social angst benytter mindre kognitiv revurdering end personer med et lavt niveau af social angst, hvis de har vanskeligt ved at skelne mellem negative emotioner ( $\mathrm{O}^{\prime}$ Toole, Jensen et al., 2014).

\section{Emotioner i psykoterapi}

At arbejde med emotionsregulering som framework er i udgangspunktet foreneligt med kognitiv adfærdsterapi, som anbefales og anvendes til flere angstlidelser og depression (NICE, 2013). Emotionsreguleringsfeltet kan f.eks. guide brugen af traditionelle kognitive metoder vha. den viden, vi nu har om, hvornår hvilke strategier har deres optimale effekt. Man kan f.eks. opfordre klienten til at bruge kognitiv revurdering som forberedelse til en angstprovokerende situation, altså inden angstresponsen er udviklet. Når det er sagt, er det blevet påpeget, at man i traditionelle kognitive adfærdsterapier har undervurderet emotionernes funktionelle rolle (Greenberg \& Safran, 1987; Mennin \& Farach, 2007), i og med man primært arbejder med at ændre negative emotioner gennem kognitive revurderinger. Emotioner ses altså - i grove træk - som et slags uønsket biprodukt som resultat af dysfunktionelle tanker, hvorved emotionernes særlige erkendelsesmæssige og tilpasningsmæssige funktion i nogen grad overses. Emotionernes funktionelle rolle har fået tiltagende opmærksomhed inden for en række nyere psykoterapiformer, herunder emotionsreguleringsterapi. 


\section{Emotionsreguleringsterapi}

Emotionsreguleringsterapi (ERT) er en af flere terapier, der har sit udgangspunkt i de affektive videnskaber og hører under det, som kaldes den tredje bølge af kognitiv adfærdsterapi efter ren adfærdsterapi (1. bølge) og den traditionelle Beckinspirerede anden bølge (Hayes, 2004). ERT er en integrativ terapiform, der trækker på kognitive, (fx psykoedukation), oplevelsesorienterede (fx Greenberg, 2002) samt mindfulness- og acceptbaserede metoder (e.g., Hayes, Strosahl, \& Wilson, 2012; Roemer \& Orsillo, 2009; Segal, Williams, \& Teasdale, 2002). ERT er mekanismefokuseret, dvs. den specifikt retter sig imod de virkningsmekanismer, modellen foreslår, leder til bedring af tilstanden. Således hævdes det ikke, at ERT overordnet set er mere effektiv end andre, lignende terapier (Mennin \& Fresco, 2014). Snarere repræsenterer ERT en psykopatologisk forklaringsmodel, rodfæstet i de affektive videnskaber, hvor en række mekanismer altså er genstand for teoretisk og empirisk udforskning. ERT præsenteres her med det formål at give et bud på, hvordan fund fra behandlingsstudier samt nyere teori og empiriske opdagelser ang. emotionsregulering kan oversættes til en model for bestemte former for psykopatologi.

ERT blev oprindelig udviklet til personer med generaliseret angst og depression, som på engelsk kaldes distress disorders, fordi de er karakteriseret ved at opleve mere intense emotioner og bruge negative selvreferentielle strategier, dvs. repetitiv og persevererende tænkning rettet mod selvet (Mennin \& Fresco, 2013). Typiske reguleringsstrategier ved disse lidelser er bekymring og rumination, hvor bekymring er gentagne spekulationer om frygtede fremtidsscenarier, medens rumination består af grublerier om fortidige negative hændelser. Bekymring og rumination kan opfattes som emotionsreguleringsstrategier, der har som formål at undgå eller neutralisere bestemte emotioner (Borkovec \& Sharpless, 2004; Mennin \& Fresco, 2013; Newman \& Llera, 2011). Personen med generaliseret angst vil således med sine bekymringer kunne berolige sig selv ved, at han/hun er forberedt på det værste. Ved at holde bekymringerne på et abstrakt, intellektuelt niveau uden konkrete forestillinger vil angstudviklingen også kunne reduceres. En person med depression kan have tendens til at ruminere over tidligere begivenheder karakteriseret ved personlige fejl og nederlag i et forsøg på at forstå en begivenhed eller løse et problem bedre. Brug af negative selvreferentielle strategier er sjældent effektive, og de kan, mod intentionen, forlænge den uønskede emotionelle respons (f.eks. Werner \& Gross, 2010). Bekymring og rumination er faktisk fundet at kunne vedligeholde angstlidelser og depression (Mennin \& Fre- 
sco, 2013; Nolen-Hoeksema, 2000; Roelofs, Huibers, Peeters, Arntz, \& van Os, 2008; Spasojevic \& Alloy, 2001). Personer med tendens til at benytte disse strategier er også fundet at profitere mindre af traditionel kognitiv adfærdsterapi (Newman, Przeworski, Fisher, \& Borkovec, 2010). Det er blevet foreslået, at en af grundende til den forringede behandlingsrespons skal findes i det forhold, at det er vanskeligt at opstille eksponeringsøvelser, der effektivt afhjælper negative selvreferentielle strategier (Borkovec \& Sharpless, 2004). ERT blev derfor udviklet med det formål specifikt at targetere disse strategier i såkaldte distress disorders. .

\section{Emotionsreguleringsterapiens tre omdrejningspunkter}

ERT har tre omdrejningspunkter, dvs. tre primære mekanismer. For det første behandler ERT motivationel funktion. Normale personer vil kunne finde en passende balance i den information, som emotionerne bringer, sådan at de kan tage hensyn til og højde for både sikkerhed og belønning (f.eks. Gray \& McNaughton, 2000). Som mennesker står vi ofte i indre, motivationelle konflikter, hvor vi både mærker tilskyndelse til at undvige og efterstræbe. Adaptive løsninger på sådanne konflikter er de løsninger, der bedst tjener både individets sikkerheds- og belønningsbehov. Dette har personer med angst og depression imidlertid vanskeligt ved (Aupperle \& Paulus, 2010; Higgins, 2001; Mennin \& Fresco, 2014). De vægter ofte sikkerhed i en sådan grad, at belønningsmuligheder overses, og de kan have vanskeligt ved overhovedet at blive opmærksom på en eventuel belønningsmotivation. Når klienten med agorafobisk undgåelse skal mødes med sin gode veninde ude i byen, kan den opfattede trussel ved at skulle forlade hjemmet helt overskygge belønningen ved at se veninden.

For det andet er et omdrejningspunkt for ERT emotionsregulering. Normalt vil individet på fleksibel vis kunne benytte passende reguleringsstrategier forstået således, at det både strategisk og automatisk vælger de strategier, der vil have den bedste effekt på et givet tidspunkt i emotionens udfoldelsesproces. Som ovenfor nævnt har studier vist, at normale personer udviser bestemte mønstre i valg af reguleringsstrategi, og at det er adaptivt både at kunne op- og nedregulere emotioner (Bonanno, Papa, Lalande, Westphal, \& Coifman, 2004; Sheppes et al., 2011). Mennesker med angst og depression udviser en rigiditet i valg af reguleringsstrategier, f.eks. i form af konsistent øget brug af selv-referentielle strategier (Mennin \& Fresco, 2013). Disse strategier kræver meget kognitiv energi og lægger beslag på personens opmærksomhedskapacitet (Muraven \& Baumesiter, 2000). Således er det blevet foreslået, at anvendelsen af disse strategier kan medvirke, at personen 
kun lægger mærke til dele af den emotionelle oplevelse og dermed løber risikoen for at overse vigtige motivationelle signaler.

Endelig deler ERT fokus med en lang række adfærdsterapier og kognitive terapier på målet om ny læring med henblik på at kunne respondere fleksibelt på såvel trussel som belønning (Mennin, Ellard, Fresco, \& Gross, 2013). For at individet optimalt kan tilpasse sig sine omgivelser, skal det have et bredt adfærdsrepertoire, som benyttes fleksibelt og afstemt efter situationen. Når personen i en given situation er opmærksomhed på de motivationelle signaler og på denne baggrund passende regulerer sine emotioner, vil det udgøre optimale betingelser for effektivt at kunne handle eller løse et problem (Gohm \& Clore, 2002). Mennesker med angst- og depressionslidelser undgår ofte angstprovokerende situationer eller udviser inaktivitet (American Psychiatric Association, 2013), som kan tolkes som et tegn på et rigidt anvendt og begrænset adfærdsrepertoire. Dertil er det karakteristisk for mennesker med angst at have en hyperopmærksomhed på trusselsignaler, hvilket antages at vanskeliggøre angstaflæring (Lohr, Olatunji, \& Sawchuk, 2007; Woody \& Rachman, 1994). For mennesker med depression, ser man tegn på vanskeligheder med at overhovedet at identificere belønningsmuligheder (Forbes, Shaw, \& Dahl, 2006)..

\section{Anvendelse af Emotionsreguleringsterapiens model}

Den kliniske anvendelse af ERT tilsvarer de tre omdrejningspunkter i modellen (se f.eks. O'Toole, Mennin \& Fresco, 2015 for en detaljeret beskrivelse af de kliniske teknikker). Som det første bliver klienten præsenteret for en række metoder, med hvilke det er målet at træne motivational bevidsthed (awareness). Ved hjælp af psykoedukation, metaforer og selv-monitoreringsopgaver inviteres klienten til at rette sin opmærksomhed mod sine emotioner og deres handletilskyndelser. Dernæst trænes klienten i fire emotionsreguleringskompetencer, der falder i to hovedgrupper: opmærksomhedsregulering og meta-kognitiv regulering. Disse to grupper af reguleringsstrategier tilsvarer opmærksomhedsallokering og kognitiv forandring i James Gross' model.

Opmærksomhedsregulering går på evnen til 1) intentionelt at rette opmærksomheden mod indre og ydre begivenheder og 2) at kunne fastholde opmærksomheden på særlige oplevelser. En øget evne til sådan opmærksomhedsregulering vil f.eks. kunne hjælpe personen til at have opmærksom på hele sin emotionelle oplevelse. Personen, der opfatter det som en trussel mod sin sikkerhed at tale foran sine studiekammerater, vil ved vha. opmærksomhedsregulering f.eks. kunne 
blive sig angstens handletilskyndelserne bevidst og måske også opdage, at der er potentielt belønnende aspekter i form af faglig sparring.

Metakognition betyder erkendelse om erkendelse. Når en person har en tanke, kan han/hun forholde sig til denne tanke metakognitivt. De to metakognitive strategier i ERT går på hhv. 1) at finde distance til sin egen følelsesmæssige oplevelse, også kendt som decentrering (Fresco et al., 2007) og 2) at kunne lave en (meta) kognitiv revurdering. Decentrering kendes også fra Acceptance and Commitment Therapy (Hayes et al., 2012), hvor man taler om defusion. At decentrere går på, at en person finder en "arbejdsafstand", fra hvilken denne ikke fusionerer med sine emotioner, men i stedet forholder sig til sine emotioner og undersøger, hvilken funktion de tjener. Denne arbejdsafstand forsøges opnået både i tid og rum, hvor klienten trænes i at betragte sig selv som andet og mere end sin emotionelle oplevelse (afstand i rum) og at kunne opfatte den emotionelle oplevelse som én ud af mange forskellige episoder, der har været og vil komme over tid (afstand i tid). I ERT opfordres klienter til at generere modige og medfølende revurderinger. For eksempel kan en klient lære at erstatte selvkritik med en medfølende revurdering ved at sige til sig selv, at hun har modet til at stå en angstprovokerende begivenhed igennem. Revurderinger i ERT adskiller sig fra kognitiv omstrukturering i traditionel kognitiv adfærdsterapi derved, at der ikke lægges vægt på at realitetskorrigere negative tanker, men derimod på at forholde sig til dem på en anderledes måde. De forskellige emotionsreguleringsstrategier, som ERT sigter mod at tillære klienten, bygger på hinanden, således at opmærksomhedsstrategierne er fundamentet for de metakognitive strategier. Strategierne kræver herved også tiltagende mere kognitiv energi, og de metakognitive bør derfor kun anvendes, når de opmærksomhedsregulerende strategier ikke er tilstrækkelige for, at personen kan handle hensigtsmæssigt.

Endelig opfordres klienter i ERT til at identificere værdier og den eventuelle diskrepans, der er mellem den måde, de ønsker at leve, versus den måde de faktisk lever på i forhold til en bestemt værdi. Eksponeringsøvelser i ERT centrerer sig om de emner, hvor denne diskrepans er størst. Udgangspunktet for tilrettelæggelsen af eksponeringsøvelser er netop klientens værdier. Klienten bliver opfordret til at identificere en handling, der er i overensstemmelse med en bestemt værdi, og som det vil være meningsfuldt for dem at kunne udføre. Som forberedelse til at kunne udføre den handling, benytter ERT sig af gestaltterapeutiske dialoger, hvor klienten fører samtale med sig selv vekslende mellem to forskellige perspektiver (Greenberg, 2002). Helt konkret bliver klienten bedt om at tale fra to stole. Fra den ene stol taler klienten med sin "værdistemme", fra den anden med sin "for- 
hindringsstemme". "Værdistemmen" afspejler en del af klienten, der finder det vigtigt at foretage handlingen, hvorfra "forhindringsstemmen" holder klienten tilbage pga. opfattede vanskeligheder.

Som eksempel kunne en enlig mand med generaliseret angst have ønske om at få en kæreste. At gå på en date ville være en handling i overensstemmelse med dén værdi, men han holder sig måske tilbage, fordi han er bange for at blive afvist. Øvelsen går da på at udforske og identificere den motivationelle konflikt, som klienten kan bære med sig som en opmærksomhed ud i selve eksponeringsopgaven efter sessionen. I dette tilfælde kunne "værdistemmen" fortælle, hvor meningsfuld og vigtig for personen et kæresteforhold ville være. "Forhindringsstemmen" vil da blive bedt om at reagere på "værdistemmens" indhold. Det kan være, stemmen understreger det potentielt ydmygende ved at rødme og ryste foran en kvinde, og måske endda selvkritik fortæller "værdistemmen" om tidligere nederlag. Klienten bliver bedt om at skifte mellem de to stole og reagere på, hvad den anden stemme siger. I løbet af øvelsen vil "forhindringsstemmen" ofte skifte karakter fra at være præget af selvreferentiel tænkning, f.eks. i form af bekymringer, til at ville beskytte individet. Ift. datingeksemplet kunne "forhindringsstemmen" tænkes at udtrykke, at denne gerne vil beskytte personen mod ydmygelse. Målet er ikke, at de to stemmer skal komme til en konklusion. Det er derimod, at klienten kan bære opmærksomheden på de to stemmers indhold med sig ud i eksponeringssituationen som to forskellige perspektiver på konflikten.

\section{ERTs målgruppe nu og i fremtiden samt begrænsninger}

Målgruppen for ERT er altså i udgangspunktet personer, der er karakteriseret ved en højere emotionalitet (dvs. oplever følelser mere intenst), og som vanemæssigt benytter sig af negative selvreferentielle strategier, hvilket er tilfældet ved kronisk angst og depression. Det er da også på personer med disse lidelser, at ERT er blevet afprøvet. Indtil videre har ERT vist sig effektiv i såvel randomiserede som ikke-randomiserede forsøg (Mennin, Fresco, Heimberg, \& Ritter, 2015; Mennin, Fresco, Heimberg, \& O’Toole, 2015) ift. reduktion af symptomer både hos personer med generaliseret angst og depression. Resultater viser, at der er tale om store effektstørrelser, der vedligeholdes over en 9 måneders opfølgningsperiode. Aktuelt pågår der en række studier, der undersøger om effekten af ERT faktisk skyldes de foreslåede mekanismer. Præliminære fund antyder, at det er tilfældet (Mennin \& Fresco, 2014; Mennin et al., 2015). F.eks. findes det, at en stigende evne til decentrering gennem terapiforløbet medierer effekten af ERT på primære 
symptommål for bekymring og depression samt den kliniske sværhedsgrad af generaliseret angst. Dertil findes det, at klienter, som oplever en stigende evne til at orientere sig i motivationelle konflikter halvvejs i terapien (målt ved Etkin emotional conflict task; Etkin \& Schatzberg, 2011), får det største udbytte af terapien (Mennin \& Fresco, 2014). Endelig undersøges det aktuelt, om ERT generelt er gavnlig for klienter med tendens til brug af selvreferentielle strategier uanset diagnose (fraset enkelte diagnoser som bipolar lidelse type I og akut psykose). En lidelse som eksempelvis socialfobi - som beskrevet med eksempler ovenfor - behandles med rimelig succes med kognitiv adfærdsterapi (NICE, 2013). Der er dog en større gruppe af disse - 40 til $50 \%$ - som ikke profiterer tilstrækkeligt af behandlingen (Hofmann \& Bögels, 2006). Derfor er der god grund til at lede efter metoder, med hvilke den eksisterende behandling kan optimeres. I og med at personer med socialfobi i nogen grad opfylder de samme kriterier som målgruppen for ERT, nemlig benytter sig af negative selvreferentielle strategier så som rumination (Clark \& Wells, 1995), kan man overveje om ERT, eller dele af ERT, ville være relevant som behandling til denne lidelse. Her tænkes særligt på de klienter, der enten ikke profiterer tilstrækkeligt af metoderne i kognitiv terapi (som kognitiv omstrukturering og eksponering), eller hvor det er særligt vanskeligt at opstille relevante eksponeringsøvelser. De samme overvejelser kunne man gøre i forhold til de øvrige angstlidelser, hvor forskellige præsentationer af samme lidelse vil være mere eller mindre i overensstemmelse med ERTs målgruppe. Hvorvidt ERT er gavnlig for andre klientgrupper er selvsagt et empirisk spørgsmål. Men overvejelserne herom bør i første omgang altså centrere sig om, hvorvidt klienten har emotionsreguleringsvanskeligheder, som ERT oprindelig blev udviklet til at takle. Om ERT kunne være gavnlig til behandlingen af andre problemstillinger, kræver grundige teoretiske overvejelser og fremtidig empirisk forskning.

Aktuelt afprøver vi ERT på pårørende til kræftpatienter i et randomiseret forsøg. Pårørende til kræftpatienter bliver i litteraturen beskrevet med symptomer på bekymringstendens og rumination og præsenterer med højere niveauer af angst og depression end kræftpatienterne selv (Applebaum \& Bretbart, 2013; O'Toole, Mennin, Renna, Zachariae, \& Applebaum, 2014). Det har, i en meta-analyse af 36 interventionsstudier, der benytter sig af kognitive metoder, vist sig, at disse interventioner ikke har nogen effekt på de pårørendes psykiske, fysiske eller sociale velbefindende, ej heller på deres generelle livskvalitet (O'Toole, Zachariae, Renna, Mennin, \& Applebaum, 2015). Et sådant fund er overraskende, givet kognitive terapiers ellers dokumenterede effekt på angst og depression i forskellige populationer. Dog er det blevet foreslået (se O'Toole, Mennin et al., 2014), at den ude- 
blivende effekt af kognitive terapier kan skyldes, at pårørende oplever en forhøjet emotionalitet som reguleres med bekymring og rumination. I tillæg hertil er de pårørende blevet beskrevet som stående overfor en række motivationelle konflikter, f.eks. at have brug for at være alene for en stund, samtidig med de oplever angst ved tanken om at forlade patienten (Applebaum, Kulikowski, \& Breitbart, 2015). Selvom der ikke i udgangspunktet er tale om egentlig psykopatologi hos de pårørende, ses der altså et overlap mellem beskrivelsen af ERTs oprindelige målgruppe og gruppen af pårørende. Dette ledte os til at udvikle en ny version af ERT (O'Toole, Mennin, Fresco, Applebaum, 2015), der indeholder de samme terapeutiske komponenter, men retter sig mod typiske pårørenderelaterede problemstillinger og kun tilbydes til pårørende, der giver udtryk for at være psykisk belastet af rolle og benytter sig af bekymring og/eller rumination. Denne version af manualen testes aktuelt både i USA og i Danmark, og resultaterne fra undersøgelsen forventes at foreligge om cirka 2 år.

Selvom procesmodellen, som ERT bl.a. bygger på, har mødt megen empirisk støtte gennem de seneste to årtier, er der ved anvendelse af modellen i såvel forskning som praksis en række begrænsninger, man må holde sig for øje. Megen forskning indenfor dette område forlader sig på selvrapportering, og man har med selvrapporteringsskemaer ofte spurgt til generelle reguleringstendenser/-strategier. Dette må dog siges at være problematisk, givet at effekten af en emotionsreguleringsstrategi er kontekstafhængig, og én strategi dermed ikke enten kun er hensigtsmæssig eller uhensigtsmæssig (Aldao et al., 2015; Gross, 2014). Dertil bør det påpeges, at et menneskeliv selvsagt ikke består af afgrænsede emotionelle episoder, hvor det står klart, hvornår en episode begynder og slutter, og herved hvornår der er tale om en forudgående eller responsmodulerende strategi. Snarere er der tale om en myriade af emotionelle episoder, der overlapper og også påvirker hinanden. Således kan det være meget vanskeligt i klinikken at afgøre, hvornår en klient er så langt i udviklingen af den emotionelle respons, at en forudgående strategi ikke længere vil have sin optimale effekt.

\section{Afrunding}

Emotioner betragtes indenfor de affektive videnskaber som en funktionel størrelse, der forbereder individet til handling mod et mål. Selvom emotioner er funktionelle, betyder det ikke, de altid er hjælpsomme. Derfor kan man få behov for at regulere sine emotioner, deraf emotionsregulering. Evnen til hensigtsmæssigt at 
regulere emotioner er nedsat ved en række psykiske lidelser, hvorfor efterhånden flere terapiformer fokuserer på måder, hvorpå man kan forbedre emotionsregulering hos personer med psykisk lidelse. ERT er et eksempel herpå. Den er udviklet med henblik på at lære klienter med generaliseret angst og depression en række kognitive og oplevelsesorienterede metoder, med hvilke de kan træne hensigtsmæssig emotionsregulering. ERT har i effektstudier vist god effekt, og fremtidige studier er planlagt med det formål at undersøge, hvad der driver denne effekt, og om målgruppen for behandlingen bør udvides. Aktuelt afprøves terapien på pårørende til kræftpatienter.

\section{Referencer}

Abbott, M. J., \& Rapee, R. M. (2004). Post-event rumination and negative self-

appraisal in social phobia before and after treatment. Journal of Abnormal Psychology, 113, 136-144.

Aldao, A., Sheppes, G., \& Gross, J. J. (2015). Emotion regulation flexibility. Cognitive Therapy and Research. Advance online publication.

American Psychiatric Association. (2013). Diagnostic and statistical manual of mental disorders (5th ed.). Arlington, VA: American Psychiatric Publishing, Inc.

Ameringen, M. V., Mancini, C., \& Farvolden, P. (2003). The impact of anxiety disorders on educational achievement. Journal of Anxiety Disorders, 17, 561-571.

Applebaum, A. J., \& Breitbart, W. (2013). Care for the cancer caregiver: A systematic review. Palliative Supportive Care, 11, 231-252.

Applebaum, A. J., Kulikowski, J. R., \& Breitbart, W (May 22nd, 2015). Meaning-Centered Psychotherapy for cancer caregivers (MCP-C): Rationale and overview. Palliative Supportive Care, 1-11.

Aupperle, R. L., \& Paulus, M. P. (2010). Neural systems underlying approach and avoidance in anxiety disorders. Dialogues in Clinical Neuroscience, 12, 517-531.

Barrett, L. F., Gross, J. J., Christensen, T. C., \& Benvenuto, M. (2001). Knowing what you're feeling and knowing what to do about it: Mapping the relation between emotion ifferentiation and emotion regulation. Cognition and Emotion, 15, 713-724.

Bonanno, G. A., Papa, A., Lalande, K., Westphal, M., \& Coifman, K. (2004). The importance of being flexible: the ability to both enhance and suppress emotional expression predicts long-term adjustment. Psychological Science, 15, 482-487.

Borkovec, T. D., \& Sharpless, B. (2004). Generalized Anxiety Disorder: Bringing Cognitive-Behavioral Therapy into the Valued Present Mindfulness and acceptance: In: S. C. Hayes, V. M. Folette, \& M. M. Linehan (Eds.), Expanding the cognitive-behavioral tradition, (pp. 209-242): Guilford Press, New York, NY.

Clark, D. M., \& Wells, A. (1995). A cognitive model of social phobia. In R. Heimberg, M. Liebowitz, D. A. Hope \& F. R. Schneier (Eds.), Social phobia: Diagnosis, assessment and treatment (pp. 69-93). New York: Guilford Press. Cole, P. M., Martin, S. E., \& 
Dennis, T. A. (2004). Emotion regulation as a scientific construct: Methodological challenges and directions for child development research. Child Development, 75, 317-333.

Cox, B. J., Fleet, C., \& Stein, M. B. (2004). Self-criticism and social phobia in the US national comorbidity survey. Journal of Affective Disorders, 82, 227-234.

Dalrymple, K. L., \& Herbert, J. D. (2007). Acceptance and commitment therapy for generalized social anxiety disorder: A pilot study. Behavior Modification, 31, 543-568.

Dunn, B. D., Billotti, D., Murphy, V., \& Dalgleish, T. (2009). The consequences of effortful emotion regulation when processing distressing material: A comparison of suppression and acceptance. Behaviour Research and Therapy, 47, 761-773.

Eisenberg, N., Hofer, C., \& Vaughan, J. (2007). Effortful control and its socioemotional consequences. In J. J. Gross (Ed.), Handbook of emotion regulation (pp. 287-306). New York: Guford Press.

Ellsworth, P. C., \& Scherer, K. R. (2009). Appraisal processes in emotion. In: R. J. Davidson, K. R. Scherer, \& H. Hill Goldsmith (Eds.). Handbook of affective sciences (pp. 572-595). New York: Oxford University Press.

Etkin, A., \& Schatzberg, A. (2011). Common abnormalities and disorder-specific compensation during implicit regulation of emotional processing in generalized anxiety versus major depressive disorders. American Journal of Psychiatry, 168, 968-978.

Forbes, E.E., Shaw, D.S., \& Dahl, R.E. (2006). Alterations in reward-related decisions in boys with depressive and anxiety disorders. Biological Psychiatry, 59, 126S-126S.

Fresco, D. M., Moore, M. T., van Dulmen, M. H. M., Segal, Z. V., Ma, H., Teasdale, J. D., \& Williams, M. G. (2007). Initial psychometric properties of the Experiences Questionnaire: Validation of a self-report measure of decentering. Behavior Therapy, 38, 234-246.

Gohm, C. L., \& Clore, G. L. (2002). Four latent traits of emotional experience and their involvement in well-being, coping, and attributional style. Cognition and Emotion, 16, 495-518.

Goldin, P. R., Manber, T., Hakimi, S., Canli, T., \& Gross, J. J. (2009). Neural bases of social anxiety disorder: Emotional reactivity and cognitive regulation during social and physical threat. Archives of General Psychiatry, 66, 170-180.

Goldin, P. R., McRae, K., Ramel, W., \& Gross, J. J. (2008). The neural bases of emotion regulation: Reappraisal and suppression of negative emotion. Biological Psychiatry, 63, 577-586.

Grant, D. M., Beck, J. G., Farrow, S. M., \& Davila, J. (2007). Do interpersonal features of social anxiety influence the development of depressive symptoms? Cognition and Emotion, 21, 646-663.

Gray, J. A., \& McNaughton, N. (2000). The Neuropsychology of Anxiety: An enquiry into the Functions of the Septo-Hippocampal System (2nd ed.). (Oxford Psychology Series No. 33). Oxford: Oxford University Press.

Greenberg, L. S. (2002). Emotion-focused therapy: Coaching clients to work through their feelings. Washington, DC: American Psychological Association.

Greenberg, L. S., \& Safran, J. D. (1987). Emotion in psychotherapy: Affect, cognition, and the process of change. New York: Guilford Press.

Gross, J. J. (1998). Antecedent- and response-focused emotion regulation: Divergent consequences for experience, expression, and physiology. Journal of Personality and Social Psychology, 74, 224-237.

Gross, J. J. (2014). Emotion regulation: Conceptual and empirical foundations. In J. J. Gross (Ed.), Handbook of emotion regulation (2nd ed., pp. 3-20). New York: The Guilford Press. 
Gross, J. J., \& John, O. P. (2003). Individual differences in two emotion regulation processes: Implications for affect, relationships, and well-being. Journal of Personality and Social Psychology, 85, 348-362.

Gross, J. J., \& Levenson, R. W. (1997). Hiding feelings: The acute effects of inhibiting negative and positive emotion. Journal of Abnormal Psychology, 106, 95-103.

Gross, J. J., \& Muñoz, R. F. (1995). Emotion regulation and mental health. Clinical Psychology: Science and Practice, 2, 151-164.

Hayes, S. C. (2004). Acceptance and Commitment Therapy, Relational Frame Theory, and the Third Wave of Behavioral and Cognitive Therapies. Behavior Therapy, 35, 639-665.

Hayes, S. C., Strosahl, K. D., \& Wilson, K. G. (2012). Acceptance and commitment therapy: The process and practice of mindful change. New York: The Guilford Press.

Higgins, E. T. (2001). Promotion and prevention experiences: Relating emotions to nonemotional motivational states. In J. P. Forgas (Ed.), Handbook of affect and social cognition (pp. 186-211). Hillsdale, NJ: Lawrence Erlbaum Associates.

Hofmann, S. G., \& Bögels, Susan M. (2006). Recent advances in the treatment of social phobia: Introduction to the special issue. Journal of Cognitive Psychotherapy, 20, 3-5.

Kashdan, T. B., Ferssizidis, P., Collins, R. L., \& Muraven, M. (2010). Emotion differentiation as resilience against excessive alcohol use: an ecological momentary assessment in underage social drinkers. Psychological Science, 21, 1341-1347.

Kashdan, T. B., \& Steger, M. F. (2006). Expanding the topography of social anxiety: An experience-sampling assessment of positive emotions, positive events, and emotion suppression. Psychological Science, 17, 120-128.

Keltner, D., \& Gross, J. J. (1999). Functional accounts of emotion. Cognition and Emotion, 13, 467-480.

Lasgaard, M., Goossens, L., Bramsen, R. H., Trillingsgaard, T., \& Elklit, A. (2011). Different sources of loneliness are associated with different forms of psychopathology in adolescence. Journal of Research in Personality, 45, 233-237.

Lazarus, R. S. (1999). Stress and emotion: A new synthesis. New York: Springer.

LeDoux, J. E. (1996). The emotional brain: The mysterious underpinnings of emotional life. New York: Simon \& Schuster.

Lohr, J. M., Olatunji, B., \& Sawchuk, C. (2007). A functional analysis of danger and safety signals in anxiety disorders. Clinical Psychology Review, 27, 114-126

Marchesi, C., Brusamonti, E., \& Maggini, C. (2000). Are alexithymia, depression, and anxiety distinct constructs in affective disorders? Journal of Psychosomatic Research, 49, 43-49.

McManus, F., Clark, D. M., \& Hackmann, A. (2000). Specificity of cognitive biases in social phobia and their role in recovery. Behavioural and Cognitive Psychotherapy, 28, 201-209.

Mennin, D. S., Ellard, K. K., Fresco, D. M., \& Gross, J. J. (2013). United we stand: Emphasizing commonalities across cognitive-behavioral therapies. Behavior Therapy, 44, 234-248.

Mennin, D. S., \& Farach, F. (2007). Emotion and evolving treatments for adult psychopathology. Clinical Psychology: Science and Practice, 14, 329-352.

Mennin, D. S., \& Fresco, D. M. (2013). What, me worry and ruminate about DSM-5 and RDoc?: The importance of targeting negative self-referential processing. Clinical Psychology: Science and Practice, 20, 259-268.

Mennin, D. S., \& Fresco, D. M. (2014). Emotion regulation therapy. In J. J. Gross (Ed.), Handbook of emotion regulation (2nd ed., pp. 469-490). New York: Guilford Press. 
Mennin, D. S., Fresco, D. M. Heimberg, R. G., \& O’Toole, M. S. (2015). Efficacy of Emotion Regulation Therapy for generalized anxiety disorder with and without comorbid depression: Evaluation in a randomized controlled trial. Manuscript in preparation.

Mennin, D. S., Fresco, D. M. Heimberg, R., \& Ritter, M. (2015). An open trial of Emotion Regulation Therapy for generalized anxiety disorder with and without comorbid major depression. Depression and Anxiety, 32, 14-23.

Mennin, D. S., Heimberg, R. G., Turk, C. L., \& Fresco, D. M. (2005). Preliminary evidence for an emotion dysregulation model of generalized anxiety disorder. Behavior Therapy and Research, 43, 1281-1310.

Muraven, M., \& Baumesiter, R. F. (2000). Self-regulation and depletion of limited resources: Does self-control resemble a muscle? Psychological Bulletin, 126, 247-259.

Newman, M. G., \& Llera, S. J. (2011). A novel theory of experiential avoidance in generalized anxiety disorder: A review and synthesis of research supporting a contrast avoidance model of worry. Clinical Psychology Review, 31, 371-382.

Newman, M. G., Przeworski, A., Fisher, A. J., \& Borkovec, T. D. (2010). Diagnostic comorbidity in adults with generalized anxiety disorder: Impact of comorbidity on psychotherapy outcome and impact of psychotherapy on comorbid diagnoses. Behavior Therapy, $41,59-72$.

NICE, National Institute for Health and Care Excellence. (2013). Social anxiety disorder: recognition, assessment and treatment. NICE clinical guideline 159. London: National Institute for Health and Care Excellence.

Nolen-Hoeksema, S. (2000). The role of rumination in depressive disorders and mixed anxiety/depressive symptoms. Journal of Abnormal Psychology, 109, 504-511.

Ochsner, K. N., Bunge, S. A., Gross, J.J., \& Gabrieli, J. D. E. (2002). Rethinking feelings: An fMRI study of the cognitive regulation of emotion. Journal of Cognitive Neuroscience, 15, 1215-1229.

O'Toole, M. S. (2014). Emotion regulation in social anxiety disorder. [PhD dissertation]. Aarhus: Department of Psychology and Behavioral Sciences, Aarhus University.

O'Toole, M. S., Hougaard, E., \& Mennin, D. S. (2013). Social anxiety and emotion knowledge: a meta-analysis. Journal of Anxiety Disorders, 27, 98-108.

O’Toole, M. S., Jensen, M. B., Fentz, H. N., Zachariae, R., \& Hougaard, E. (2014). Emotion differentiation and emotion regulation in high and low socially anxious individuals: An experience-sampling study. Cognitive Therapy and Research, 38, 428-438.

O'Toole, M. S., Mennin, D. S., \& Fresco, D. M. (2015). Emotion Regulation Therapy: An experiential approach to chronic anxiety and recurring depression. In N. Thoma \& D. McKay (Eds.), Working with emotion in cognitive-behavioral therapy: Techniques for clinical practice. New York: Guilford Press.

O'Toole, M. S., Mennin, D. S., Fresco, D. M., \& Applebaum, A. (2015). Emotion Regulation Therapy for cancer caregivers. Therapist manual and client workbook. [unpublished document].

O’Toole, M. S., Mennin, D. S., Hougaard, E., Zachariae, R., \& Rosenberg, N. K. (2014). Cognitive and emotion regulation change processes in cognitive behavioral therapy for social anxiety disorder. Clinical Psychology and Psychotherapy. Advance online publication.

O’Toole, M. S., Mennin, D. S., Renna, M., Zachariae, R., \& Applebaum, A. (2014). Cognitive behavioral therapy for informal cancer caregivers: A review of the literature and future 
directions. In: B. Myers (Ed.), Cognitive Behavioral Therapy: New Research. Hauppage, NY: Nova Science Publishers.

O'Toole, M. S., Pedersen, A. D., Hougaard, E., \& Rosenberg, N. K. (2015). Neuropsychological test performance in social anxiety disorder. Nordic Journal of Psychiatry, 23, 1-9.

O’Toole, M. S., Zachariae, R., Renna, M. E., Mennin, D. S., \& Applebaum, A. (2015). Cognitive behavioral therapy for informal caregivers of patients with cancer and cancer survivors: A metaanalysis. Manuscript resubmitted to Journal of Clinical and Consulting Psychology.

Richards, J. M., \& Gross, J. J. (2000). Emotion regulation and memory: The cognitive costs of keeping one's cool. Journal of Personality and Social Psychology, 79, 410-424.

Richards, J. M., \& Gross, J. J. (2006). Personality and emotional memory: How regulating emotion impairs memory for emotional events. Journal of Research in Personality, 40, 631651.

Roelofs J., Huibers M., Peeters F., Arntz A., \& van Os J. (2008). Rumination and worrying as possible mediators in the relation between neuroticism and symptoms of depression and anxiety in clinically depressed individuals. Behaviour Research and Therapy, $46,1283-1289$.

Roemer, L., \& Orsillo, S. M. (2009). Mindfulness- \& acceptance-based behavioral therapies in practice. New York: The Guilford Press.

Roseman, I. J., \& Smith, C. A. (2001). Appraisal theory: Overview, assumptions, varieties, controversies. In: K. R. Scherer, A. Schorr, \& T. Johnstone (Eds.). Appraisal processes in emotion (pp. 3-19). New York: Oxford University Press, Inc.

Scherer, K. R. (2000). Psychological models of emotion. In: J. Borod (Ed.). The neuropsychology of emotion (pp. 137-162). Oxford/New York: Oxford University Press.

Scherer, K. R. (2009). Introduction: Cognitive components of emotion. In: R. J. Davidson, K. R. Scherer, \& H. Hill Goldsmith (Eds.). Handbook of affective sciences (pp. 563-571). New York: Oxford University Press.

Segal, Z. V., Williams, J. M. G., \& Teasdale, J. D. (2002). Mindfulness-based cognitive therapy for depression: A new approach to preventing relapse. New York: Guilford.

Sheppes, G., Scheibe, S., Suri, G., \& Gross, J. J. (2011). Emotion-regulation choice. Psychological Science, 22, 1391-1396.

Spasojevic, J., \& Alloy, L. B. (2001). Rumination as a common mechanism relating depressive risk factors to depression. Emotion, 1, 25-37.

Srivastava, S., Tamir, M., McGonigal, K. M., John, O. P., \& Gross, J. J. (2009). The social costs of emotional suppression: A prospective study of the transition to college. Journal of Personality and Social Psychology, 96, 883-897.

Stein, M. B., \& Paulus, M. P. (2009). Imbalance of approach and avoidance: The yin and aang of anxiety disorders. Biological Psychiatry, 66, 1072-1074.

Turk, C. L., Heimberg, R. G., Luterek, J. A., Mennin, D. S., \& Fresco, D. M. (2005). Emotion Dysregulation in Generalized Anxiety Disorder: A Comparison with Social Anxiety Disorder. Cognitive Therapy and Research, 29, 89-106.

Wells, A., Clark, D. M., Salkovskis, P., Ludgate, J., Hackmann, A., \& Gelder, M.

(1995). Social phobia: The role of in-situation safety behaviors in maintaining anxiety and negative beliefs. Behavior Therapy, 26, 153-161.

Werner, K. H., \& Gross, J. J. (2010). Emotion regulation and psychopathology. In D. S. Sloan \& A. M. Kring (Eds.), Emotion regulation and psychopathology (pp. 13-37). New York: The Guilford Press. 
Woody, S., \& Rachman, S. (1994). Generalized anxiety disorder (GAD) as an unsuccessful search for safety. Clinical Psychology Review, 14, 745-753. 